\title{
Renal Cell Carcinoma with Angioleiomyoma-Like Stroma and Clear Cell Papillary \\ Renal Cell Carcinoma: Exploring SDHB Protein Immunohistochemistry and the
} Relationship to Tuberous Sclerosis Complex

Sean R Williamson, $\mathrm{MD}^{1,2}$, Jason L Hornick MD, $\mathrm{PhD}^{3}$, John N Eble $\mathrm{MD}^{4}$, Nilesh S Gupta $\mathrm{MD}^{1}$, Craig G Rogers $\mathrm{MD}^{5}$, Lawrence True $\mathrm{MD}^{6}$, David J Grignon $\mathrm{MD}^{4}$, and Liang Cheng ${ }^{4}$

${ }^{1}$ Department of Pathology and Laboratory Medicine and Henry Ford Cancer Institute, Henry Ford Health System, Detroit, MI, USA; ${ }^{2}$ Department of Pathology, Wayne State University School of Medicine, Detroit, MI, USA. ${ }^{3}$ Department of Pathology, Brigham and Women's Hospital and Harvard Medical School, Boston, MA, United States; ${ }^{4}$ Department of Pathology and Laboratory Medicine, Indiana University School of Medicine, Indianapolis, IN, USA, ${ }^{5}$ attikutti Urology Institute, Henry Ford Health System, Detroit, MI, USA; and ${ }^{6}$ Department of Pathology, University of Washington, Seattle, WA, United States

This work was presented in part at the United States and Canadian Academy of Pathology Annual Meeting, 2015, Boston, MA, USA (Mod Pathol 2015; 28:267A)

Address correspondence and reprint requests to:

Sean R. Williamson, MD

Henry Ford Hospital, Department of Pathology - K6

2799 West Grand Blvd 
Detroit, MI 48202

Email: swilli25@hfhs.org

Phone: 313-916-3986

Fax: 313-916-2385

Conflicts of Interest and Source of Funding: None 


\section{ABSTRACT}

Renal cell carcinoma (RCC) with angioleiomyoma-like stroma appears to be molecularly distinct from clear cell RCC; however, its relationship to clear cell papillary RCC remains debated. Recent studies have found that similar tumors sometimes occur in patients with tuberous sclerosis complex (TSC), of which one study found unexpectedly negative succinate dehydrogenase (SDH) B immunostaining. We evaluated immunohistochemistry for SDHB in 12 apparently sporadic RCCs with angioleiomyoma-like stroma and correlated with clinical information for stigmata of TSC. Tumors were compared to a group of 16 clear cell papillary RCCs and 6 unclassified tumors with prominent stroma. With exception of 1 unclassified tumor, all exhibited at least focal cytoplasmic staining for SDHB protein, often requiring high magnification and better appreciated with increased antibody concentration. Detailed history information was available for $9 / 12$ patients with smooth muscle-rich tumors, revealing no stigmata of undiagnosed TSC. Electron microscopy performed on 1 of these tumors revealed mitochondria to be very sparse, potentially accounting for the weak immunohistochemical labeling for SDHB protein. Weak SDHB immunostaining may represent another shared feature of RCC with angioleiomyoma-like stroma and clear cell papillary RCC, likely due to sparse mitochondria, strengthening the possible relationship of these entities. Although smooth muscle-rich tumors have been recently reported in patients with TSC, absence of staining in tumors with this pattern may not be specific for TSC. In tumors with pale or clear cytoplasm, immunohistochemical staining for SDHB should be interpreted with caution as evidence of abnormality in the SDH pathway. 
Key words: renal cell carcinoma; tuberous sclerosis; succinate dehydrogenase; clear cell papillary renal cell carcinoma;

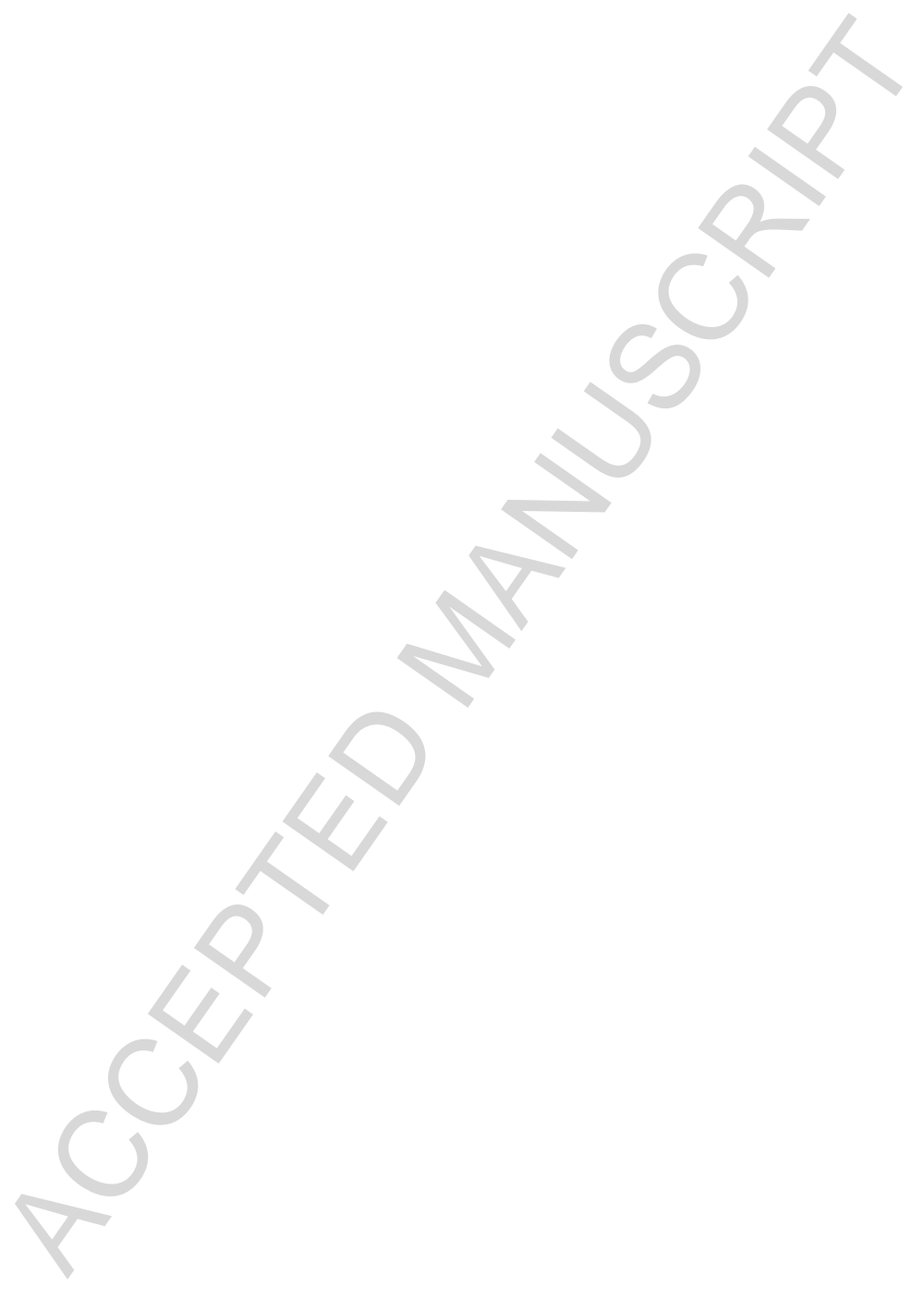




\section{Introduction}

Renal cell carcinomas with angioleiomyoma-like stroma $(1,2)$ and likely related entities renal cell carcinoma with smooth muscle stroma $(3,4)$ and renal angiomyoadenomatous tumor, $(5,6)$ are thought to be immunohistochemically and molecularly distinct from clear cell renal cell carcinoma. $(2,7)$ However, it remains debated whether these tumors should be regarded as variants of clear cell papillary renal cell carcinoma,(8-10) due to the shared features of cytokeratin 7 and high molecular weight keratin immunohistochemical labeling and lack of reactivity for alpha-methyl-acyl-coAracemase (AMACR), combined with absence of other defining genetic alterations. $(2,7)$

Interestingly, two recent reports have noted a tendency to encounter a similar morphology in patients with tuberous sclerosis complex, $(11,12)$ of which one study found the tumors to be unexpectedly negative for succinate dehydrogenase B (SDHB) immunohistochemical staining.(12) We therefore sought to assess SDHB immunohistochemical staining in a cohort of apparently sporadic tumors with smooth muscle stroma, to determine whether negative staining is consistently associated with this morphology, or with tuberous sclerosis-associated tumors.

\section{Materials and Methods}

A cohort of 12 renal cell carcinomas with angioleiomyoma-like stroma from 11 patients were selected for analysis, of which 10 tumors from 9 patients were previously reported(2) and 2 represent additional unpublished cases. These were compared to 16 clear cell papillary renal cell carcinoma tumors and 6 unclassified tumors with prominent 
stroma, not fitting cleanly into a distinct category. The unclassified group included 1 tumor that upon review was interpreted as likely sarcomatoid renal cell carcinoma with the spindle-shaped cell component mimicking myoid stroma, 2 which had suggestive morphology and immunohistochemical phenotype but were shown to have chromosome $3 p$ deletion using fluorescence in situ hybridization (FISH), 1 that had similar morphology and immunohistochemical staining pattern but was predominantly papillary (even more strongly resembling the tuberous sclerosis-associated morphology), and 1 that had borderline features between renal cell carcinoma with angioleiomyoma-like stroma and clear cell papillary renal cell carcinoma, all of which had been in the excluded group from a prior series.(2)

Immunohistochemistry for SDHB was performed on 4-micrometer thick formalinfixed paraffin-embedded tissue sections following pressure cooker antigen retrieval (Target Retrieval Solution, pH 6.1; Dako, Carpinteria, CA) using a mouse monoclonal antibody directed against SDHB (at both 1:100 and 1:50 dilutions; 40 min incubation; clone 21A11AE7, Abcam, Cambridge, MA). Control cases of known SDH-deficient tumors were also tested at the increased concentration to confirm that their abnormal negative staining was retained under these conditions. Detailed clinical, imaging, and family history was available for $9 / 11$ of the patients with renal cell carcinoma with angioleiomyoma-like stroma to evaluate for stigmata of undiagnosed tuberous sclerosis. For electron microscopy, formalin-fixed but unprocessed tissue was retrieved from the remaining gross specimen after initial histologic examination in 1 renal cell carcinoma with angioleiomyoma-like stroma. This was subsequently fixed in glutaraldehyde, and processed according to routine protocol for clinical transmission electron microscopy in 
the Henry Ford Health System electron microscopy laboratory. This study was approved by the Institutional Review Board of the Henry Ford Health System.

\section{Results}

In renal cell carcinoma with angioleiomyoma-like stroma (Figure 1) and clear cell papillary renal cell carcinoma, SDHB immunohistochemical staining appeared nearnegative when performed at usual antibody concentration (1:100). Examination at high magnification and repeated analysis with increased antibody concentration (1:50) revealed at least focal fine cytoplasmic granular staining in all tumors. Detailed clinical, imaging, and family history information was available for 9 of 11 patients with renal cell carcinoma with angioleiomyoma-like stroma and revealed no angiomyolipomas or other findings to indicate undiagnosed tuberous sclerosis, although family histories revealed renal cysts and renal cancer in 2 patients and end-stage renal disease in 1. Immunohistochemistry remained equivocal (no definite positivity) in only 1 unclassified tumor (cytokeratin 7 positive with clear cell morphology, but chromosome 3p deletion by FISH), even at the higher antibody concentration. Follow-up imaging in this patient revealed a solitary renal angiomyolipoma but no other lesions to suggest tuberous sclerosis, including no lesions identified by MRI of the brain. One unclassified tumor that even more strongly resembled the predominant papillary architecture of the tuberous sclerosis-associated tumors $(11,12)$ (Figure 2) also exhibited focal granular staining under high magnification and at higher antibody concentration. Electron microscopy was performed on 1 renal cell carcinoma with angioleiomyoma-like stroma revealed mitochondria to be very sparse (Figure 3). 


\section{Discussion}

A rare and unusual group of renal cell tumors appears to share common features of nests and glands composed of cells with clear cytoplasm, combined with fibromuscular stroma and immunohistochemical reactivity for cytokeratin 7. Many of these have been found thus far to lack the typical genetic characteristics of clear cell renal cell carcinoma,(1-7, 13-17) although there are likely examples of clear cell renal cell carcinoma with chromosome $3 p$ loss or $V H L$ alterations that mimic this morphology for various reasons. $(2,7)$ The category of such renal cell tumors with prominent stroma has been referred to by several names, including renal cell carcinoma with angioleiomyoma-like stroma, renal cell carcinoma with smooth muscle stroma, renal angiomyoadenomatous tumor, among others, $(1-7,13-17)$ and to date it remains incompletely understood whether all of these represent a single entity, and whether any or all should be considered a variant of clear cell papillary renal cell carcinoma.

The most recent International Society of Urological Pathology Vancouver Classification of Renal Neoplasia(18) and World Health Organization Classification(19) both largely place such tumors in the category of "provisional" or "emerging" entities, noting that some may be variants of clear cell papillary renal cell carcinoma, particularly those previously reported as renal angiomyoadenomatous tumor.(20) Although these usually share with clear cell papillary renal cell carcinoma the findings of immunohistochemical reactivity for cytokeratin 7, high molecular weight keratin, and carbonic anhydrase IX, with minimal or negative labeling for AMACR, they differ slightly in variably higher nuclear grade, positivity for CD10, and more robust myoid differentiation of the stroma.(2) They also appear to be much rarer than clear cell papillary 
renal cell carcinoma, which is now recognized to be likely the $4^{\text {th }}$ most common renal cell carcinoma subtype.(21-23)

The recent recognition of a similar morphology in patients with tuberous sclerosis $(11,12)$ raises the question of whether encountering this tumor morphology is a harbinger of undiagnosed tuberous sclerosis, whether these tumors are associated with tuberous sclerosis gene alterations in both the hereditary and sporadic settings (similar to $V H L$ in clear cell renal cell carcinoma), or whether this morphology is enriched in tuberous sclerosis patients for other reasons. We reviewed medical histories from our cohort of patients, finding no conclusive evidence of tuberous sclerosis in this study; however, a recent abstract noted the opposite, with several patients meeting diagnostic criteria for tuberous sclerosis.(24) As such, our current working hypothesis is that this tumor morphology may occur both with tuberous sclerosis and sporadically, similar to what has been recently reported for the novel entity eosinophilic solid and cystic renal cell carcinoma, $(25,26)$ although further study is needed.

One of the two studies of renal cancers in tuberous sclerosis patients found that the papillary renal cell carcinomas with fibromuscular stroma were abnormally negative for SDHB immunohistochemical staining,(12) an unexpected finding, since SDHB loss is intuitive in the setting of germline SDH subunit gene alterations(27-29) but not in the setting of TSC1 and TSC2 gene mutations. Therefore, we sought to assess whether this abnormal lack of SDHB staining in renal cell tumors is specific for the angioleiomyomalike stroma morphology, associated with tuberous sclerosis patients specifically, or occurs for other reasons. We found that although staining is typically very weak, at least focal cytoplasmic granular labeling can be appreciated in almost all of these tumors, especially 
when staining is performed at higher antibody concentration and when viewed a high magnification. Electron microscopy in 1 tumor demonstrated very sparse mitochondria, which suggests that decreased mitochondrial density may be responsible for this nearnegative or false negative staining pattern.

Of note, another recent abstract found decreased mitochondrial density in clear cell papillary renal cell carcinoma, in contrast to clear cell renal cell carcinoma and recently described entity TCEB1 mutant renal cell carcinoma,(30) adding additional support to this hypothesis. Our data showing similar weak staining in both entities (clear cell papillary renal cell carcinoma and tumors with angioleiomyoma-like stroma), combined with the results of Sarungbam et al(30) represent yet another potential link between these entities, perhaps supporting the concept that these represent a spectrum of the same disease, despite their differences. Of note, however, no convincing evidence of metastatic behavior has yet been reported from the comparatively large number of clear cell papillary renal cell carcinomas reported to date, casting doubt on whether these tumors should be considered malignant,(31) whereas the study by Verkarre et al found lymph node involvement associated with the considerably rarer renal tumors with angioleiomyoma-like stroma.(24)

In summary, renal cell carcinoma with angioleiomyoma-like (or smooth muscle) stroma is a rare renal neoplasm with an incompletely understood relationship to tuberous sclerosis. Although it has been recently found in tuberous sclerosis patients that similar tumors have abnormal negative immunohistochemical staining for SDHB, we found that in the apparently sporadic counterparts, at least focal granular normal staining is appreciable, underscoring that interpretation should be approached with caution in tumors with clear cytoplasm,(32) especially clear cell papillary renal cell carcinoma and renal cell carcinoma 
with angioleiomyoma-like stroma, which may share the finding of very low mitochondrial density.(30) Further study is needed to determine whether this tumor morphology has any implications for diagnosis of tuberous sclerosis.

Acknowledgements: Sources of funding - none

\author{
References:
}

1. Kuhn E, De Anda J, Manoni S, Netto G, Rosai J. Renal cell carcinoma associated with prominent angioleiomyoma-like proliferation: Report of 5 cases and review of the literature. Am J Surg Pathol 2006; 30, 1372-81.

2. Williamson SR, Cheng L, Eble JN, True LD, Gupta NS, Wang M, et al. Renal cell carcinoma with angioleiomyoma-like stroma: clinicopathological, immunohistochemical, and molecular features supporting classification as a distinct entity. Mod Pathol 2015; 28, 279-94.

3. Shannon BA, Cohen RJ, Segal A, Baker EG, Murch AR. Clear cell renal cell carcinoma with smooth muscle stroma. Hum Pathol 2009; 40, 425-9.

4. Iczkowski KA, Shanks JH, Burdge AH, Cheng L. Renal cell carcinoma with clear cells, smooth muscle stroma, and negative for $3 p$ deletion: a variant of renal angiomyoadenomatous tumour? A case report. Histopathology 2013; 62, 522-4.

5. Michal M, Hes O, Havlicek F. Benign renal angiomyoadenomatous tumor: a previously unreported renal tumor. Ann Diagn Pathol 2000; 4, 311-5. 
6. Michal M, Hes O, Nemcova J, Sima R, Kuroda N, Bulimbasic S, et al. Renal angiomyoadenomatous tumor: morphologic, immunohistochemical, and molecular genetic study of a distinct entity. Virchows Arch 2009; 454, 89-99.

7. Peckova K, Grossmann P, Bulimbasic S, Sperga M, Perez Montiel D, Daum O, et al. Renal cell carcinoma with leiomyomatous stroma--further immunohistochemical and molecular genetic characteristics of unusual entity. Ann Diagn Pathol 2014; 18, 291-6.

8. Deml KF, Schildhaus HU, Comperat E, von Teichman A, Storz M, Schraml P, et al. Clear cell papillary renal cell carcinoma and renal angiomyoadenomatous tumor: two variants of a morphologic, immunohistochemical, and genetic distinct entity of renal cell carcinoma. Am J Surg Pathol 2015; 39, 889-901.

9. Aron M, Chang E, Herrera L, Hes O, Hirsch MS, Comperat E, et al. Clear cellpapillary renal cell carcinoma of the kidney not associated with end-stage renal disease: clinicopathologic correlation with expanded immunophenotypic and molecular characterization of a large cohort with emphasis on relationship with renal angiomyoadenomatous tumor. Am J Surg Pathol 2015; 39, 873-88.

10. Hes O, Comperat EM, Rioux-Leclercq N. Clear cell papillary renal cell carcinoma, renal angiomyoadenomatous tumor, and renal cell carcinoma with leiomyomatous stroma relationship of 3 types of renal tumors: a review. Ann Diagn Pathol 2016; 21, 59-64.

11. Guo J, Tretiakova MS, Troxell ML, Osunkoya AO, Fadare O, Sangoi AR, et al. Tuberous sclerosis-associated renal cell carcinoma: a clinicopathologic study of 57 separate carcinomas in 18 patients. Am J Surg Pathol 2014; 38, 1457-67.

12. Yang P, Cornejo KM, Sadow PM, Cheng L, Wang M, Xiao Y, et al. Renal cell carcinoma in tuberous sclerosis complex. Am J Surg Pathol 2014; 38, 895-909. 
13. Kuroda N, Hosokawa T, Michal M, Hes O, Sima R, Ohe C, et al. Clear cell renal cell carcinoma with focal renal angiomyoadenomatous tumor-like area. Ann Diagn Pathol $2011 ; 15,202-6$.

14. Kuroda N, Michal M, Hes O, Taguchi T, Tominaga A, Mizobuchi K, et al. Renal angiomyoadenomatous tumor: fluorescence in situ hybridization. Pathol Int 2009; 59, 68991.

15. Sahni VA, Hirsch MS, Silverman SG. Renal angiomyoadenomatous tumour: Imaging features. Can Urol Assoc J 2012; 6, E140-3.

16. Singh C, Kendi AT, Manivel JC, Pambuccian SE. Renal angiomyoadenomatous tumor. Ann Diagn Pathol 2012; 16, 470-6.

17. Verine J. Renal angiomyoadenomatous tumor: morphologic, immunohistochemical, and molecular genetic study of a distinct entity. Virchows Arch $2009 ; 454,479-80$.

18. Srigley JR, Delahunt B, Eble JN, Egevad L, Epstein JI, Grignon D, et al. The International Society of Urological Pathology (ISUP) Vancouver Classification of Renal Neoplasia. Am J Surg Pathol 2013; 37, 1469-89.

19. Moch H, Amin M, Argani P, Cheville J, Delahunt B, Martignoni G, et al. Renal cell tumors. In: Moch H, Humphrey P, Ulbright T, Reuter V, eds. WHO classification of tumours of the urinary system and male genital organs. Lyon: International Agency for Research on Cancer, 2016, p. 14-7.

20. Srigley JR, Cheng L, Grignon DJ, Tickoo SK. Clear cell papillary renal cell carcinoma. In: Moch H, Humphrey PA, Ulbright T.M., Reuter VE, eds. WHO 
Classification of Tumours of the Urinary System and Male Genital Organs. Lyon:

International Agency for Research on Cancer, 2016, p. 40-1.

21. Alexiev BA, Drachenberg CB. Clear cell papillary renal cell carcinoma: Incidence, morphological features, immunohistochemical profile, and biologic behavior: A single institution study. Pathol Res Pract 2014; 210, 234-41.

22. Williamson SR, Eble JN, Cheng L, Grignon DJ. Clear cell papillary renal cell carcinoma: differential diagnosis and extended immunohistochemical profile. Mod Pathol $2013 ; 26,697-708$.

23. Zhou H, Zheng S, Truong LD, Ro JY, Ayala AG, Shen SS. Clear cell papillary renal cell carcinoma is the fourth most common histologic type of renal cell carcinoma in 290 consecutive nephrectomies for renal cell carcinoma. Hum Pathol 2014; 45, 59-64.

24. Verkarre V, Mensah A, Leroy X, Sibony M, Vasiliu V, Comperat E, et al. A Clinico-Pathologic Study of 17 Patients With Renal Cell Carcinoma Associated With Leiomyomatous Stroma Identifies a Strong Association With Tuberous Sclerosis. Lab Invest 2015; 95, 266A.

25. Trpkov K, Abou-Ouf H, Hes O, Lopez JI, Nesi G, Comperat E, et al. Eosinophilic Solid and Cystic Renal Cell Carcinoma (ESC RCC): Further Morphologic and Molecular Characterization of ESC RCC as a Distinct Entity. Am J Surg Pathol 2017.

26. Trpkov K, Hes O, Bonert M, Lopez JI, Bonsib SM, Nesi G, et al. Eosinophilic, Solid, and Cystic Renal Cell Carcinoma: Clinicopathologic Study of 16 Unique, Sporadic Neoplasms Occurring in Women. Am J Surg Pathol 2016; 40, 60-71.

27. Barletta JA, Hornick JL. Succinate dehydrogenase-deficient tumors: diagnostic advances and clinical implications. Adv Anat Pathol 2012; 19, 193-203. 
28. Gill AJ, Hes O, Papathomas T, Sedivcova M, Tan PH, Agaimy A, et al. Succinate dehydrogenase (SDH)-deficient renal carcinoma: a morphologically distinct entity: a clinicopathologic series of 36 tumors from 27 patients. Am J Surg Pathol 2014; 38, 1588602.

29. Williamson SR, Eble JN, Amin MB, Gupta NS, Smith SC, Sholl LM, et al. Succinate dehydrogenase-deficient renal cell carcinoma: detailed characterization of 11 tumors defining a unique subtype of renal cell carcinoma. Mod Pathol 2015; 28, 80-94.

30. Sarungbam J, Reznik E, Hakimi AA, Bialik A, Sirintrapun SJ, Al Ahmadie H, et al. Clear Cell Papillary Renal Cell Carcinoma Shows Marked Depletion of Mitochondrial Content: A Comparative Differential Diagnostic Study. Mod Pathol 2016; 29, 260A-1A. 31. Williamson SR, Cheng L. Clear cell renal cell tumors: not all that is "clear" is cancer. Urol Oncol 2016; 34, 292 e17-22.

32. Cornejo KM, Lu M, Yang P, Wu S, Cai C, Zhong WD, et al. Succinate dehydrogenase B: a new prognostic biomarker in clear cell renal cell carcinoma. Hum Pathol 2015; 46, 820-6.

\section{Figure Legends}

Figure 1: (A, 100× magnification, hematoxylin and eosin) Renal cell carcinoma with angioleiomyoma-like stroma is composed of glandular structures dispersed in fibromuscular stroma, lined by cells with clear cytoplasm. (B, 200× magnification, hematoxylin and eosin) Higher magnification reveals nests and glandular structures with 
clear to eosinophilic cytoplasm in abundant muscular stroma. $(\mathrm{C}, 600 \times$ magnification, antiSDHB immunohistochemical staining) Immunohistochemistry for SDHB performed at usual antibody concentration (1:100 dilution) appeared near-negative, although faint, focal cytoplasmic staining was observed (D, 600× magnification, anti-SDHB immunohistochemical staining) Repeated analysis with increased antibody concentration (1:50) revealed sparse but recognizable cytoplasmic granules.

Figure 2: (A, 100× magnification, hematoxylin and eosin) This unclassified renal cell carcinoma demonstrated the papillary configuration with prominent muscular papillary cores that has been recently described as one subtype of renal tumor in patients with tuberous sclerosis. (B, 400× magnification, hematoxylin and eosin) Higher magnification reveals the papillary structures to be lined by cells with clear to flocculent or eosinophilic cytoplasm and readily identifiable nucleoli. (C, 600× magnification, anti-SDHB immunohistochemical staining) Immunohistochemistry for SDHB appeared near-negative, with minimal trace cytoplasmic labeling, prompting re-evaluation with higher antibody concentration. (D, 600 $\times$ magnification, anti-SDHB immunohistochemical staining) At antibody dilution of 1:50, cytoplasmic granules were readily appreciable in the same tumor.

Figure 3: (A) Electron microscopy was performed in one renal cell carcinoma with angioleiomyoma-like stroma tumor, and revealed the neoplastic glands to be lined by cells with voluminous granular cytoplasm and small, abortive brush border elements (direct magnification 2200×, scale bar $4 \mu \mathrm{m}$ ). (B) Mitochondria were sparsely distributed within 
the epithelial cells' cytoplasm (direct magnification $5600 \times$, scale bar $2 \mu \mathrm{m}$ ), potentially explaining the scant immunohistochemical labeling for SDHB protein (a mitochondrial protein). 


\section{ACCEPTED MANUSCRIPT}

Williamson et al - Smooth muscle renal cell carcinoma
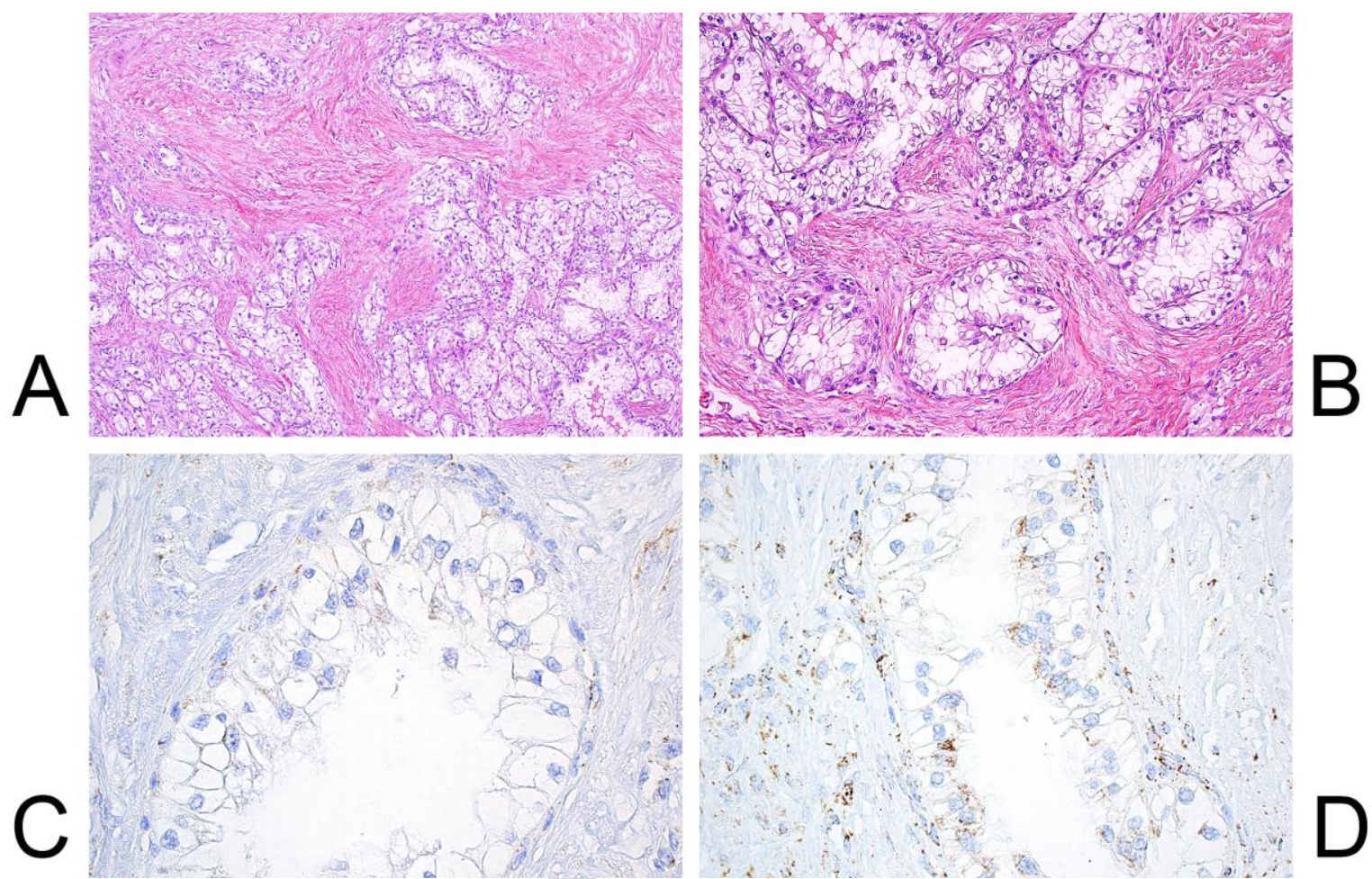

Figure 1

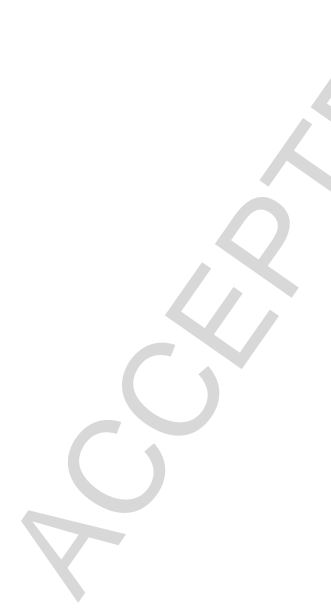




\section{ACCEPTED MANUSCRIPT}

Williamson et al - Smooth muscle renal cell carcinoma
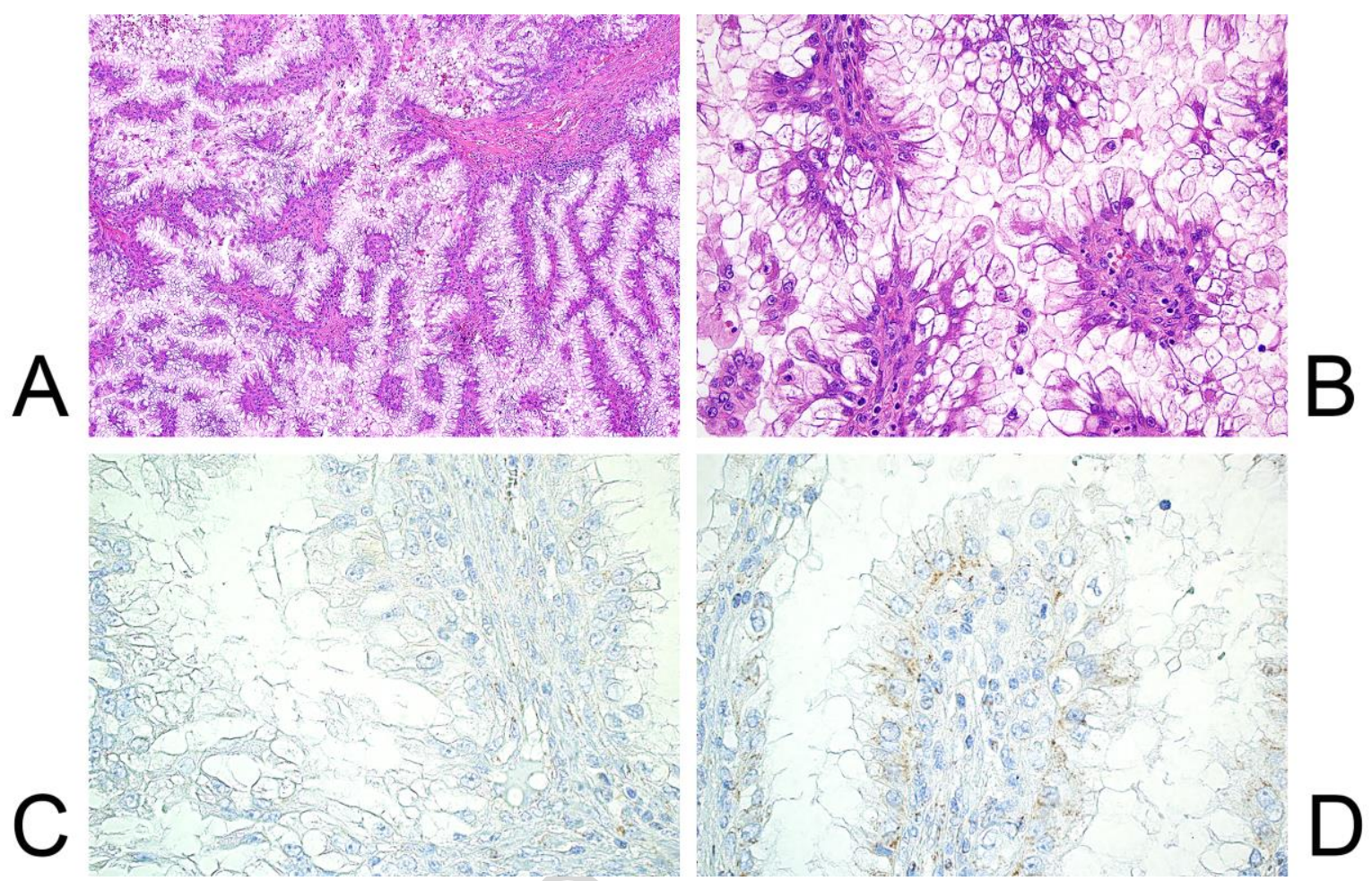

Figure 2 
Williamson et al - Smooth muscle renal cell carcinoma
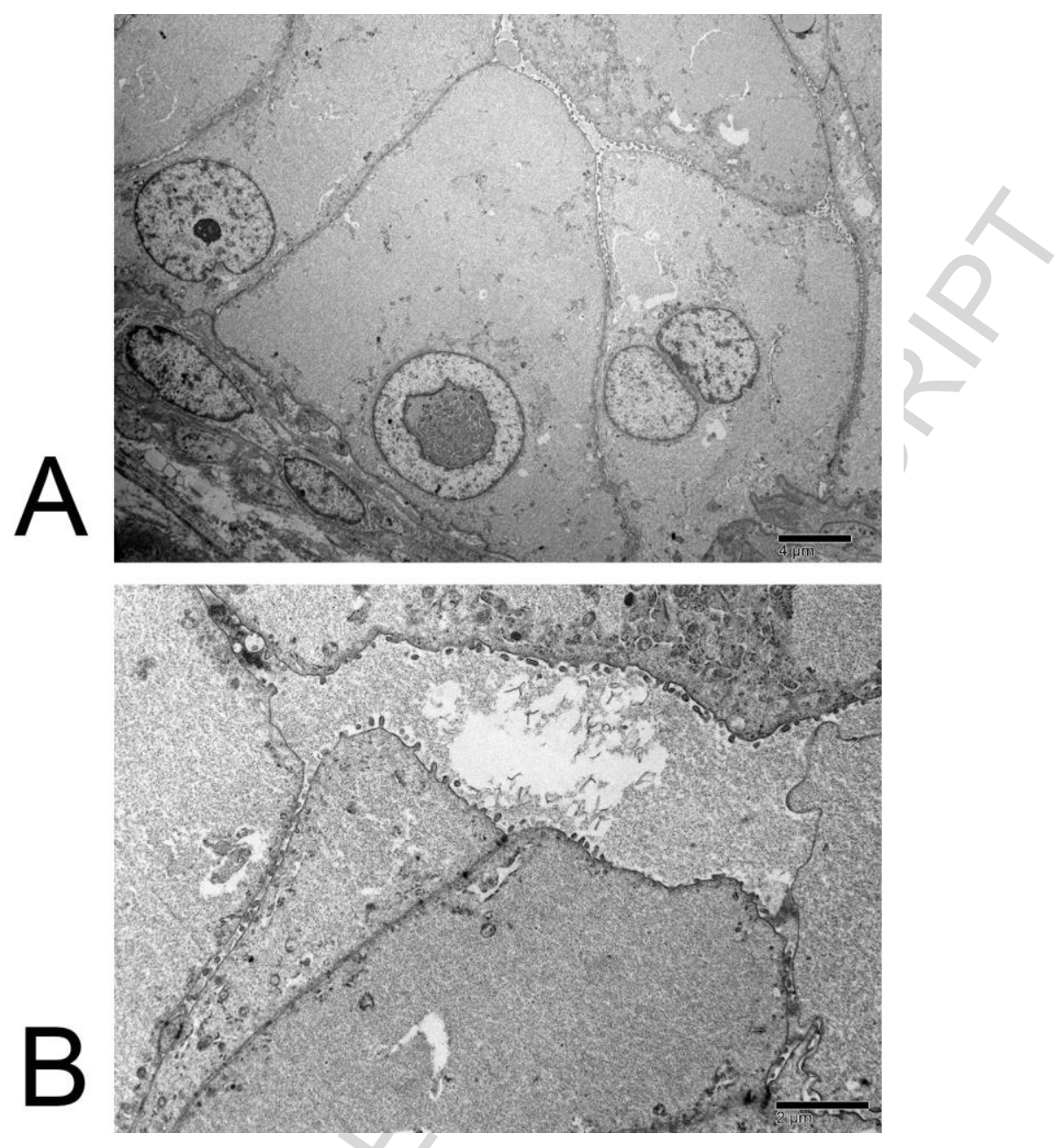

Figure 3

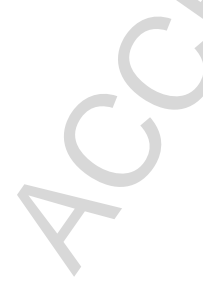


- SDHB staining is weak but focally present in renal tumors with smooth muscle stroma

- Clear cell papillary renal cell carcinoma exhibits a similar staining pattern

- These findings are likely the result of sparse mitochondria rather than protein defect

- Further study is needed to determine if this is tumor is related to tuberous sclerosis 